Selcuk Journal of Agriculture and Food Sciences

http://sjafs.selcuk.edu.tr/sjafs/index

Research Article
SJAFS

(2021) 35 (2), 141-146

e-ISSN: $2458-8377$

DOI:10.15316/SJAFS.2021.241

\title{
Salicylic Acid Treatments for Extending Postharvest Quality of Tomatoes Maintained at Different Storage Temperatures
}

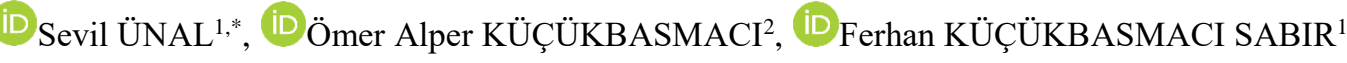 \\ ${ }^{1}$ Selçuk University, Faculty of Agriculture, Department of Horticulture, Konya, Turkey \\ ${ }^{2}$ Selçuk University, Graduate School of Natural and Applied Science, Konya, Turkey
}

\begin{tabular}{l}
\hline ARTICLE INFO \\
\hline Article history: \\
Received date: 31.05 .2021 \\
Accepted date: 02.07 .2021 \\
\hline
\end{tabular}

Keywords:

Salicylic acid

Tomato

Postharvest

Quality

\begin{abstract}
Salicylic acid (SA) is known to be an effective tool on extending the postharvest quality of horticultural commodities by preventing synthesis and movement of ethylene. Thus, the present study was established to study the effect of different dozes of SA treatments $(0.5 \mathrm{mM}, 1.0 \mathrm{mM}$ and $2.0 \mathrm{mM})$ on extending postharvest quality of pink maturity tomatoes maintained at two different storage conditions $\left(5{ }^{\circ} \mathrm{C}\right.$ with $90 \%$ relative humidity and $20{ }^{\circ} \mathrm{C}$ with $65 \%$ relative humidity). SA treatment at all doses significantly retarded weight loss at both storage conditions. SA treated tomatoes were firmer, higher in titratable acidity, and exhibited less biochemical changes than the control fruit at the end of storage. Among the applied dozes, SA at $2 \mathrm{mM}$ can be recommended as it was pioneering for most of the parameters analyzed during cold storage at both $5{ }^{\circ} \mathrm{C}$ for $20 \mathrm{~d}$ and at $20^{\circ} \mathrm{C}$ for $10 \mathrm{~d}$. SA treatment may be recommended as an environmental friendly, healthy and sustainable method for extending postharvest quality of tomatoes cold storage and shelf life, without significant adverse effect on produces.
\end{abstract}

\section{Introduction}

Tomato is one of the most important vegetable crops grown in Turkey. According to 2018 statistical data, 12.8 million tons of tomatoes are produced in Turkey, which corresponds to approx. $7 \%$ of the total world production (180 million tons) (Anonymous 2021). Tomato fruits are an important vegetable crops and are among major contributor of carotenoids (especially lycopene), phenolics, vitamin $\mathrm{C}$ and small amounts of vitamin $\mathrm{E}$ in daily diets (Gautier et al. 2008).

Tomatoes are climacteric fruits and their ripening is highly depended on ethylene action (Mostofi et al. 2003; Guillen et al. 2007). The rapid ripening of fruit after harvest limits storability and is a concern during transportation and marketing. Ethylene synthesis and action in tomatoes can be affected by low temperature storage, controlled or modified atmosphere and application of ethylene antagonists (Feng et al. 2004; Sabir and Agar 2011).

Salicylic acid (SA), a phenolic compound found in a wide range of plant species, exhibits a high potential in controlling the postharvest losses of horticultural crops. Postharvest SA treatments decrease the ethylene biosynthesis and action, induce the resistance towards

\footnotetext{
*Corresponding author email: sozcelik@selcuk.edu.tr
}

disease, prevent oxidative stresses, support the fruit tolerance to chilling injury, decrease respiration rate, delay ripening and senescence, slow down the activity of cell wall degrading enzymes and maintain the crop firmness (Asghari and Aghdam 2010).

Application of exogenous SA at non-toxic concentrations to fruit has been shown to inhibit respiration and ethylene production of plum (Luo et al. 2011) and apricot (Erbaş et al. 2015). Postharvest exogenous application of SA, delayed over-ripening in fruits like kiwifruit (Zhang et al. 2003), sweet cherries (Valero et al, 2011) and peach (Sabir et al. 2019). Furthermore, treatments with SA alleviated chilling injury of tomatoes (Aghdam et al. 2012) and pomegranates (Sayyari 2011).

The objective of the present study was to evaluate the effect of different concentrations of SA $(0.5 \mathrm{mM}$, $1.0 \mathrm{mM}$ and $2.0 \mathrm{mM}$ ) and storage temperatures (20 and $5{ }^{\circ} \mathrm{C}$ ) on extending the postharvest quality attributes of tomatoes (Lycopersicon esculentum Mill.) during storage.

\section{Materials and Methods}

Tomatoes (Lycopersicon esculentum Mill.) cv. 'Durinta' were harvested from commercial field in Cumra, Turkey at pink maturity stage using the United States Department of Agriculture tomato ripeness color classification chart (USDA 1991) and immediately 
transferred to the laboratory of the Department of Horticulture at Selcuk University. Afterwards, fruits were selected for unity and freedom from defects and blemishes, tomatoes were randomly divided into four equal lots. First lot was evaluated as a control group untreated while three lots were assigned to different concentrations of SA $(0.5 \mathrm{mM}, 1.0 \mathrm{mM}$ and $2.0 \mathrm{mM})$ treatments. Each group further divided into two lots for different storage temperatures $\left(5\right.$ and $\left.20^{\circ} \mathrm{C}\right)$.

SA (Sigma- Aldrich 69-72-7) treatments were performed by dipping fruits in $5 \mathrm{~L}$ of solution for $5 \mathrm{~min}$ at ambient temperature $\left(22^{\circ} \mathrm{C}\right)$ with the addition of $0.01 \%$ Tween 20 (Merck 9005-64-5) surfactant, and then fruits were left to dry at room temperature. Treated and untreated fruits were stored at $5{ }^{\circ} \mathrm{C}$ (cold storage with $90 \%$ relative humidity) for $20 \mathrm{~d}$ or $20{ }^{\circ} \mathrm{C}$ (ambient temperature with $65 \%$ relative humidity) for $10 \mathrm{~d}$ in open boxes. Fruit quality attributes was evaluated after $0,2,4,7$ or $10 \mathrm{~d}$ at ambient temperature and $0,5,10$, 15 or $20 \mathrm{~d}$ at cold storage.

The weight loss (\%) during postharvest storage was determined by periodical weighing, and calculated by dividing the weight change during storage by the initial weight:

Weight loss $(\%)=[(\mathrm{Wi}-\mathrm{Ws}) / \mathrm{Wi}] \times 100$, where $\mathrm{Wi}=$ initial weight and $\mathrm{Ws}=$ weight at examined time.

Fruit firmness was measured using a digital penetrometer (fruit pressure tester, model 53205; TR, Forlì, Italy) with an $8 \mathrm{~mm}$ probe. Ten fruits in each replication were pressed at opposite sides of their equatorial axes. Results were expressed as Newton (N).

Skin color of ten tomatoes per treatment was analyzed using a colorimeter (Minolta ${ }^{\circledR}$ CR-400) to obtain the following variables from two equatorial points of fruits: $L^{*}, a^{*}, b^{*}$. Results were calculated as hue angle $\left(h^{\circ}\right)$ using equations described by McGuire (1992).

Tomato juice squeezed from fruit was analyzed for total soluble solid content (SSC) using a refractometer (Atago, Tokyo, Japan) and results were expressed as $\%$. Titratable acidity (TA) was determined by titrating

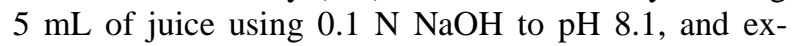
pressed as \% citric acid. The ratio between SSC and TA was also calculated as ripening index (RI).

Lycopene content of tomatoes was performed as previously described by Sharma and Maguer (1996); Rao et al. (1998) with slight modifications. For lycopene analysis, pericarp tissue of tomatoes was blended with a warring blender for $1 \mathrm{~min}$. One gram of homogeneous tissue and $50 \mathrm{~mL}$ hexane:ethanol:acetone $(2: 1: 1, \mathrm{v} / \mathrm{v})$ were shaken for $30 \mathrm{~min}$. After shaking, 10 $\mathrm{mL}$ of distilled water were added and shaken for $5 \mathrm{~min}$ again. The solution was then placed in a separator funnel and, after phase separation, the upper phase was collected. The extract was filtered via Whatman No. 42 filter paper and lycopene concentration was determined by measuring the absorbance of the solution at $502 \mathrm{~nm}$ using a UV-visible spectrophotometer. Results were expressed as $\mathrm{mg} \mathrm{kg}^{-1}$ fresh fruit weight.
The experiment was a completely randomized design with three replications and each replication contained 15 fruits. Data from analyzed parameters were subjected to analysis of variance separately. Sources of variation were treatment, storage time and their interaction. Means were compared by Student's t-test at P $\leq$ 0.05, using JMP statistical software version 5.1 (SAS Institute Inc., Cary, NC, USA).

\section{Results and Discussion}

For both storage conditions, the percentage of weight loss increased during prolonged storage for control and all SA treatments (figure 1) while the effect of SA treatments on weight loss was found statistically significant. At the end of the cold storage, the greatest loss in weight occurred in non-treated control tomatoes $(2.06 \%)$, while the lowest value was obtained from 1.0 mM SA (1.71\%). As for the tomatoes stored at $20{ }^{\circ} \mathrm{C}$, similar weight loss course was seen with that of the cold storage findings. Accordingly, all the treatments significantly restricted the loss in weight during the storage at $20{ }^{\circ} \mathrm{C}$, with more pronounced effect following $4^{\text {th }} \mathrm{d}$. Among them, SA treatments at $1.0 \mathrm{mM}$ resulted in the lowest loss in weight with the value $4.43 \%$, which was followed by $0.5 \mathrm{mM} \mathrm{SA}(3.50 \%)$. On the other hand, the weight loss in $2 \mathrm{mM}$ SA tomatoes was as high as $3.78 \%$, resulting from a progressive increment in moisture loss from produces along with the storage at ambient temperature. The weight loss is known to be the major determinant of storage life and quality of fresh commodities (Sabir and Agar 2011) and mainly regulated by respiration, transpiration and metabolic activities in fruits. SA has been reported to close stomata which results in suppressed respiration rate and minimized weight loss of fruits (Tareen et al. 2012). According to the more recent studies, postharvest SA treatment was effective in delayed the weight loss in various horticultural products such as apple (Sabir et al. 2013), plum (Davarynejad et al. 2015), apricot (Erbaş et al. 2015) and peach (Tareen et al. 2012). Thus, the results of this study suggest that SA might have reduced respiration and transpiration which concomitantly delayed weight loss. As illustrated in figure 2, firmness of the fruits gradually decreased during the prolonged storage in both storage conditions. However, all SA treatments significantly maintained the fruit firmness in comparison to control fruits. Initial firmness value of tomatoes were $41.7 \mathrm{~N}$. At the end of the cold storage period, the highest firmness value was obtained from $2.0 \mathrm{mM}$ SA treatment $(34.5 \mathrm{~N})$, followed by 1.0 and $0.5 \mathrm{mM} \mathrm{SA}$ treatments (29.4 and $27.5 \mathrm{~N}$, respectively). On the other hand, fruits of control treatment showed the lowest firmness value $(26.6 \mathrm{~N})$. Firmness of the tomatoes also underwent a significant decrease during their storage at $20{ }^{\circ} \mathrm{C}$. At the end of the experiment, firmness values were $27.7 \mathrm{~N}, 25.8 \mathrm{~N}, 24.5 \mathrm{~N}$ and 22.9 $\mathrm{N}$ for $2.0 \mathrm{mM} \mathrm{SA}, 1.0 \mathrm{mM} \mathrm{SA}, 0.5 \mathrm{mM} \mathrm{SA}$ and control, respectively. Results indicated $2.0 \mathrm{mM} \mathrm{SA}$ 
treatment significantly delayed the softening compared to control. Similar results were also obtained by Awad (2013) who reported that $0.5,1.0$ and $1.5 \mathrm{mM} \mathrm{SA}$

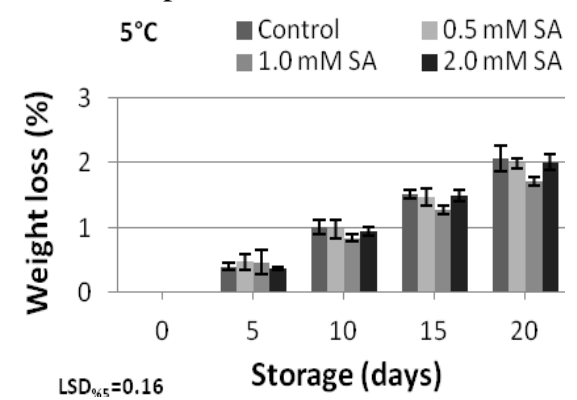

significantly inhibited the decrease of firmness in peach fruits.

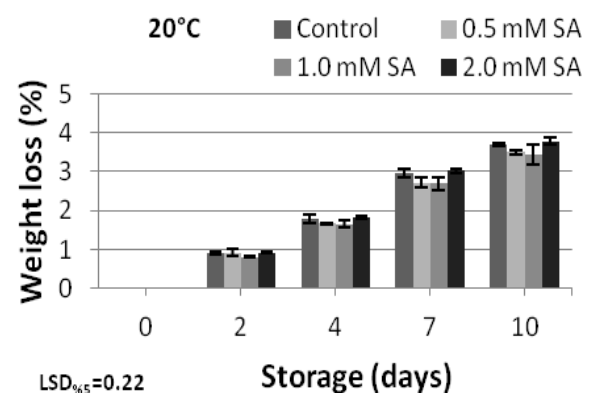

Figure 1

Effects of SA on weight loss $(\%)$ of tomato during cold storage at $5{ }^{\circ} \mathrm{C}$ and ambient temperature storage at $20{ }^{\circ} \mathrm{C}$. Each bar represents the mean of three replicates of 5 fruits each. Vertical bars represent the standard deviation of that mean.
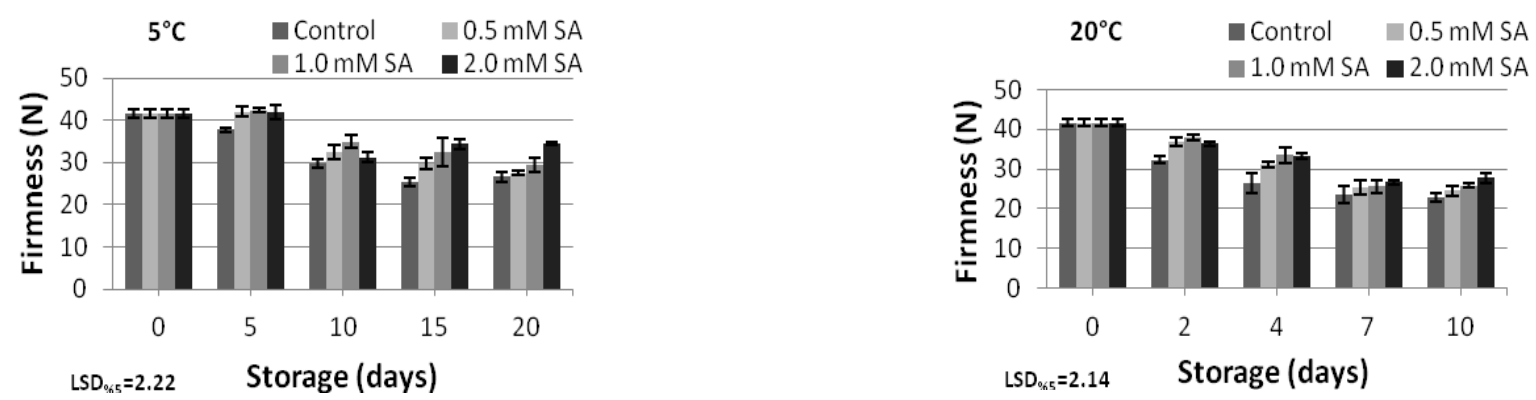

Figure 2

Effects of SA on firmness $(\mathrm{N})$ of tomato during cold storage at $5{ }^{\circ} \mathrm{C}$ and ambient temperature storage at $20^{\circ} \mathrm{C}$. Each data point represents the mean of three replicate samples. Vertical bars represent the standard deviation of that mean.

Changes in the fruit skin color related values during cold and ambient storage conditions were shown in figure 3. Decrease in the fruit skin hue angle value was recorded with the prolonged storage time in both storage condition, but the differences between the treatments were statistically insignificant. At harvest, $\mathrm{h}^{\circ}$ value of fruit skin was $49.3^{\circ}$. At the end of the cold storage, the highest $h^{\circ}$ value was obtained from the fruits of the control fruits $\left(48.1^{\circ}\right)$, while the lowest

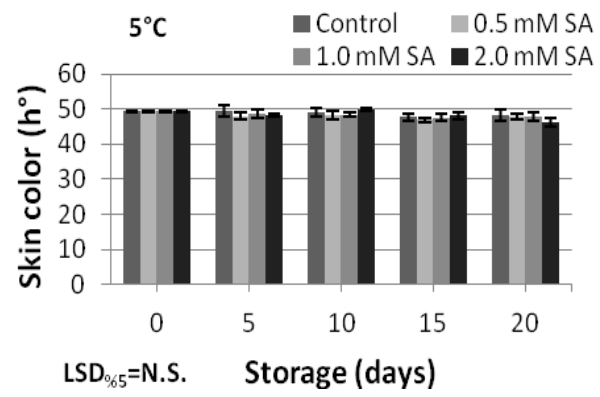

value was measured in the $2.0 \mathrm{mM}$ SA treated fruits $\left(46.1^{\circ}\right) \cdot h^{\circ}$ value of the tomatoes also decreased along with the storage at $20{ }^{\circ} \mathrm{C}$ similar to cold storage findings. Finally, $\mathrm{h}^{\circ}$ values of fruit skin ranged from $43.8^{\circ}(2.0 \mathrm{mM} \mathrm{SA})$ to $42.5^{\circ}$ (control). Tomato color is greatly correlated with lycopene content, and as the fruit develops from the mature green stage to the red stage, lycopene concentration increases significantly (Nunes 2008).

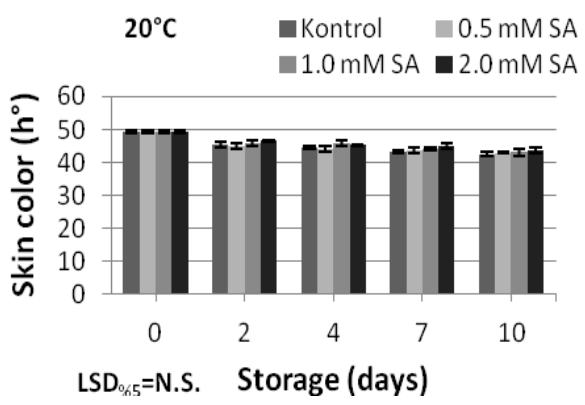

Figure 3

Effects of SA on skin color $\left(\mathrm{h}^{\circ}\right)$ of tomato during cold storage at $5{ }^{\circ} \mathrm{C}$ and ambient temperature storage at $20^{\circ} \mathrm{C}$. Each data point represents the mean of three replicate samples. Vertical bars represent the standard deviation of that mean.

In general, SSC underwent a slight but insignificant increase through the storage (table 1). At the harvest, SSC contents of fruits were $4.70 \%$. These values increased during the storage regardless from treatments. At the end of the storage, the highest SSC was observed in control $(5.03 \%)$, while the least value was recorded in $0.5 \mathrm{mM} \mathrm{SA}(4.53 \%)$. Some researchers reported that single use of SA treatment had no effect on SSC of several fruits like grape (Ranjbaran et al. 2011) and persimmon (Khademi et al. 2012).

TA values tended to reduce during the cold storage across the applications. TA was $0.517 \%$ at harvest while at the end of the storage ranged from $0.410 \%$ (control) to $0.473 \%$ (2.0 mM SA). During the ambient storage conditions, TA also decreased during the 
storage. The highest TA was observed in $2.0 \mathrm{mM} \mathrm{SA}$ $(0.420 \%)$, followed by $1.0 \mathrm{mM} \mathrm{SA}(0.413 \%)$ and control $(0.397 \%)$ while the least value was recorded in $0.5 \mathrm{mM} \mathrm{SA}(0.373 \%)$ at 10 days (table 2$) .2 .0 \mathrm{mM} \mathrm{SA}$ treatment significantly prevented TEA decline in both Table 1

Effects of SA on SSC, TEA, SSC/TA and lycopene of tomato during cold storage $\left(5^{\circ} \mathrm{C}\right)$.

\begin{tabular}{|c|c|c|c|c|c|}
\hline \multirow[t]{2}{*}{ Treatments } & \multicolumn{5}{|l|}{ Storage (days) } \\
\hline & 0 & 5 & 10 & 15 & 20 \\
\hline \multicolumn{6}{|l|}{ SSC } \\
\hline Control & \multirow[t]{4}{*}{$4.70 \pm 0.17$} & $4.93 \pm 0.12$ & $4.73 \pm 0.12$ & $4.97 \pm 0.06$ & $5.03 \pm 0.06$ \\
\hline $0.5 \mathrm{mM} \mathrm{SA}$ & & $4.93 \pm 0.42$ & $4.67 \pm 0.12$ & $4.50 \pm 0.35$ & $4.53 \pm 0.35$ \\
\hline $1.0 \mathrm{mM} \mathrm{SA}$ & & $5.00 \pm 0.20$ & $4.67 \pm 0.23$ & $4.50 \pm 0.10$ & $4.77 \pm 0.12$ \\
\hline $2.0 \mathrm{mM} \mathrm{SA}$ & & $5.00 \pm 0.00$ & $4.93 \pm 0.12$ & $4.53 \pm 0.25$ & $4.83 \pm 0.12$ \\
\hline \multicolumn{6}{|l|}{ TA } \\
\hline Control & \multirow[t]{4}{*}{$0.517 \pm 0.031 \mathrm{a}$} & $0.422 \pm 0.012 \mathrm{fgh}$ & $0.420 \pm 0.010 \mathrm{fgh}$ & $0.405 \pm 0.012 \mathrm{~h}$ & $0.410 \pm 0.010 \mathrm{gh}$ \\
\hline $0.5 \mathrm{mM} \mathrm{SA}$ & & $0.500 \pm 0.020 \mathrm{abc}$ & $0.437 \pm 0.032 \mathrm{~d}-\mathrm{h}$ & $0.450 \pm 0.026 \mathrm{def}$ & $0.442 \pm 0.023 \mathrm{~d}-\mathrm{g}$ \\
\hline $1.0 \mathrm{mM} \mathrm{SA}$ & & $0.508 \pm 0.035 \mathrm{ab}$ & $0.430 \pm 0.017 \mathrm{e}-\mathrm{h}$ & $0.428 \pm 0.010 \mathrm{fgh}$ & $0.455 \pm 0.012 \mathrm{def}$ \\
\hline $2.0 \mathrm{mM} \mathrm{SA}$ & & $0.472 \pm 0.010 \mathrm{bcd}$ & $0.467 \pm 0.012$ cde & $0.453 \pm 0.015 \mathrm{def}$ & $0.473 \pm 0.032 \mathrm{bcd}$ \\
\hline \multicolumn{6}{|l|}{$\mathrm{SSC} / \mathrm{TA}$} \\
\hline Control & \multirow[t]{4}{*}{$9.10 \pm 0.084 \mathrm{f}$} & $11.71 \pm 0.08 \mathrm{abc}$ & $11.28 \pm 0.40 \mathrm{bcd}$ & $12.27 \pm 0.32 \mathrm{ab}$ & $12.30 \pm 0.36 \mathrm{a}$ \\
\hline $0.5 \mathrm{mM} \mathrm{SA}$ & & $9.84 \pm 0.42$ ef & $10.71 \pm 0.78 \mathrm{de}$ & $9.98 \pm 0.17$ ef & $10.30 \pm 1.18 \mathrm{de}$ \\
\hline $1.0 \mathrm{mM} \mathrm{SA}$ & & $9.85 \pm 0.31$ ef & $10.83 \pm 0.18 \mathrm{cde}$ & $10.52 \pm 0.45 \mathrm{de}$ & $10.48 \pm 0.37 \mathrm{de}$ \\
\hline $2.0 \mathrm{mM} \mathrm{SA}$ & & $10.59 \pm 0.20 \mathrm{de}$ & $10.59 \pm 0.45 \mathrm{de}$ & $10.01 \pm 0.59$ ef & $10.27 \pm 0.85 \mathrm{e}$ \\
\hline \multicolumn{6}{|l|}{ Lycopene } \\
\hline Control & \multirow[t]{4}{*}{$28.85 \pm 1.02 \mathrm{~d}-\mathrm{g}$} & $27.91 \pm 0.88 \mathrm{~d}-\mathrm{g}$ & $29.41 \pm 1.06 \mathrm{cde}$ & $32.58 \pm 1.24 \mathrm{~b}$ & $35.20 \pm 3.08 \mathrm{a}$ \\
\hline $0.5 \mathrm{mM} \mathrm{SA}$ & & $27.39 \pm 1.29 \mathrm{efg}$ & $29.99 \pm 0.99 \mathrm{~cd}$ & $33.66 \pm 1.62 \mathrm{ab}$ & $35.44 \pm 1.73 \mathrm{a}$ \\
\hline $1.0 \mathrm{mM} \mathrm{SA}$ & & $26.83 \pm 0.74 \mathrm{fg}$ & $29.20 \pm 0.93 \mathrm{def}$ & $29.93 \pm 1.28 \mathrm{~cd}$ & $31.82 \pm 1.90 \mathrm{bc}$ \\
\hline $2.0 \mathrm{mM} \mathrm{SA}$ & & $26.48 \pm 1.32 \mathrm{~g}$ & $26.94 \pm 1.21 \mathrm{fg}$ & $28.86 \pm 2.13 \mathrm{~d}-\mathrm{g}$ & $28.79 \pm 1.91 \mathrm{~d}-\mathrm{g}$ \\
\hline \multicolumn{6}{|c|}{ LSD for SSC: N.S., TA: 0.04, SSC/TA: 0.99, Lycopene: 2.43} \\
\hline \multicolumn{6}{|l|}{ Table 2} \\
\hline \multicolumn{6}{|c|}{ Effects of SA on SSC, TA, SSC/TA and lycopene of tomato during ambient storage $\left(20^{\circ} \mathrm{C}\right)$. } \\
\hline \multirow[t]{2}{*}{ Treatments } & \multicolumn{5}{|c|}{ Storage (days) } \\
\hline & 0 & 2 & 4 & 7 & 10 \\
\hline \multicolumn{6}{|l|}{ SSC } \\
\hline Control & $4.70 \pm 0.17$ & $4.07 \pm 0.12$ & $4.73 \pm 0.12$ & $4.06 \pm 0.03$ & $4.53 \pm 0.23$ \\
\hline $0.5 \mathrm{mM} \mathrm{SA}$ & & $4.27 \pm 0.06$ & $4.67 \pm 0.12$ & $4.06 \pm 0.03$ & $4.47 \pm 0.12$ \\
\hline $1.0 \mathrm{mM} \mathrm{SA}$ & & $4.23 \pm 0.06$ & $4.93 \pm 0.12$ & $4.08 \pm 0.01$ & $4.67 \pm 0.12$ \\
\hline $2.0 \mathrm{mM} \mathrm{SA}$ & & $4.33 \pm 0.06$ & $4.67 \pm 0.31$ & $4.40 \pm 0.17$ & $4.67 \pm 0.12$ \\
\hline \multicolumn{6}{|l|}{ TA } \\
\hline Control & $0.517 \pm 0.031 \mathrm{a}$ & $0.483 \pm 0.015 \mathrm{bc}$ & $0.442 \pm 0.003$ ef & $0.399 \pm 0.012 \mathrm{gh}$ & $0.398 \pm 0.006 \mathrm{gh}$ \\
\hline $0.5 \mathrm{mM} \mathrm{SA}$ & & $0.453 \pm 0.012 \mathrm{de}$ & $0.433 \pm 0.015$ ef & $0.430 \pm 0.017$ ef & $0.376 \pm 0.021 \mathrm{~h}$ \\
\hline $1.0 \mathrm{mM} \mathrm{SA}$ & & $0.436 \pm 0.021 \mathrm{ef}$ & $0.455 \pm 0.023 \mathrm{cde}$ & $0.427 \pm 0.015 \mathrm{efg}$ & $0.413 \pm 0.015 \mathrm{fg}$ \\
\hline $2.0 \mathrm{mM} \mathrm{SA}$ & & $0.493 \pm 0.006 \mathrm{ab}$ & $0.476 \pm 0.015 \mathrm{bcd}$ & $0.416 \pm 0.012 \mathrm{fg}$ & $0.420 \pm 0.017 \mathrm{fg}$ \\
\hline \multicolumn{6}{|l|}{ SSC/TA } \\
\hline Control & $9.10 \pm 0.084 \mathrm{ghi}$ & $8.40 \pm 0.13 \mathrm{i}$ & $10.72 \pm 0.30 \mathrm{bcd}$ & $10.18 \pm 0.38 \mathrm{c}-\mathrm{f}$ & $11.41 \pm 0.77 \mathrm{ab}$ \\
\hline $0.5 \mathrm{mM} \mathrm{SA}$ & & $9.43 \pm 0.33 \mathrm{fgh}$ & $10.79 \pm 0.42 \mathrm{bcd}$ & $9.43 \pm 0.35 \mathrm{fgh}$ & $11.91 \pm 0.59 \mathrm{a}$ \\
\hline $1.0 \mathrm{mM} \mathrm{SA}$ & & $9.73 \pm 0.62 \mathrm{e}-\mathrm{h}$ & $10.85 \pm 0.40 \mathrm{bc}$ & $9.55 \pm 0.24 \mathrm{fgh}$ & $11.32 \pm 0.58 \mathrm{ab}$ \\
\hline $2.0 \mathrm{mM} \mathrm{SA}$ & & $8.77 \pm 0.07 \mathrm{hi}$ & $9.82 \pm 1.01 \mathrm{~d}-\mathrm{g}$ & $10.59 \pm 0.65 \mathrm{~b}-\mathrm{e}$ & $11.12 \pm 0.12 \mathrm{abc}$ \\
\hline \multicolumn{6}{|l|}{ Lycopene } \\
\hline Control & $28.85 \pm 1.02 \mathrm{i}$ & $35.31 \pm 1.32 \mathrm{~d}$ & $34.87 \pm 1.06 \mathrm{de}$ & $34.57 \pm 0.73 \mathrm{def}$ & $47.18 \pm 2.31 \mathrm{a}$ \\
\hline $0.5 \mathrm{mM} \mathrm{SA}$ & & $32.62 \pm 2.23 \mathrm{gh}$ & $28.69 \pm 0.88 \mathrm{i}$ & $29.28 \pm 0.85 \mathrm{i}$ & $39.56 \pm 0.19 \mathrm{~b}$ \\
\hline $1.0 \mathrm{mM} \mathrm{SA}$ & & $33.71 \pm 0.69 \mathrm{~d}-\mathrm{g}$ & $32.18 \pm 1.23 \mathrm{gh}$ & $34.77 \pm 1.23 \mathrm{def}$ & $39.04 \pm 0.13 \mathrm{bc}$ \\
\hline $2.0 \mathrm{mM} \mathrm{SA}$ & & $31.68 \pm 0.47 \mathrm{~h}$ & $32.98 \pm 0.95 \mathrm{fgh}$ & $33.28 \pm 0.48$ e-h & $37.19 \pm 1.20 \mathrm{c}$ \\
\hline
\end{tabular}

storage conditions. These observations were well adjusted to the findings of Sayyari et al. (2009) on pomegranates, Davarynejad et al. (2015) on plum and Bal (2012) on cherry.

LSD for SSC: N.S., TA: 0.03, SSC/TA: 0.97, Lycopene: 1.86 
During storage, SSC/TA values tended to increase in various levels according to the treatments in both storage conditions. SSC/TA ratio of tomatoes 9.10 at harvest. At the end of the $20 \mathrm{~d}$ cold storage duration, the highest SSC/TA value was determined in control fruits (12.30), while the lowest ratio was calculated in $2.0 \mathrm{mM} \mathrm{SA}$ treated fruits (10.27). SSC/TA of the tomatoes markedly increased along with the storage at $20{ }^{\circ} \mathrm{C}$ similar to cold storage findings. After 10 days of storage at $20^{\circ} \mathrm{C}, \mathrm{SS} / \mathrm{TA}$ ratios were $11.91,11.41,11.32$ and 11.12 for $0.5 \mathrm{mM} \mathrm{SA}$, control, $1.0 \mathrm{mM} \mathrm{SA}$ and 2.0 $\mathrm{mM}$ SA, respectively. During the storage period, it was determined that postharvest $2.0 \mathrm{mM}$ treatments effectively delayed the increase in SSC/TA value compared to control.

Changes in lycopene content of tomatoes during the cold storage at $5{ }^{\circ} \mathrm{C}$ were presented in table 1 . Initial lycopene content of tomatoes was $28.85 \mathrm{mg} \mathrm{kg}^{-1}$ and underwent a remarkable increase due to ripening advancement, with the greatest change in control along with the prolonged storage. $2.0 \mathrm{mM}$ SA treatment significantly delayed the initiation of lycopene synthesis during cold storage. At the end of storage, the highest lycopene values were determined in control fruits $\left(35.20 \mathrm{mg} \mathrm{kg} \mathrm{g}^{-1}\right)$, while the lowest lycopene amount was detected in $2.0 \mathrm{mM}$ SA treated fruits (28.79 $\mathrm{mg} \mathrm{kg}^{-1}$ ). During ambient storage conditions, lycopene content increase with prolonged storage period. In control and SA treatments, this increase reached maximum level in 10 days. Lycopene values varied from $37.19 \mathrm{mg} \mathrm{kg}^{-1}$ (2 mM SA) to $47.18 \mathrm{mg}$ $\mathrm{kg}^{-1}$ (control) at the end of storage.

\section{Conclusion}

The storability and shelf life of tomatoes are limited due to their perishable texture and accelerated ripening after harvest. Salicylic acid (SA), known to be an effective tool on extending the postharvest quality of horticultural commodities by preventing synthesis and movement of ethylene, was tested at various doses $(0.5$ $\mathrm{mM}, 1.0 \mathrm{mM}$ and $2.0 \mathrm{mM}$ ) for effectiveness on postharvest quality maintenance of tomatoes stored at two different storage conditions $\left(5{ }^{\circ} \mathrm{C}\right.$ with $90 \%$ relative humidity and $20{ }^{\circ} \mathrm{C}$ with $65 \%$ relative humidity). SA treatment at all doses remarkably retarded weight loss at both storage conditions. Changes in firmness and many other biochemical features were retarded by SA. Among the applied dozes, SA at $2 \mathrm{mM}$ can be recommended as it was pioneering for most of the parameters analyzed during cold storage at both $5{ }^{\circ} \mathrm{C}$ for $20 \mathrm{~d}$ and at $20{ }^{\circ} \mathrm{C}$ for $10 \mathrm{~d}$. SA treatment may be recommended as an environmental friendly, healthy and sustainable method for extending postharvest quality of tomatoes cold storage and shelf life, without significant adverse effect on produces.

\section{References}

Aghdam MS, Asghari MR, Moradbeygi H, Mohammadkhani N, Mohayeji M, Rezapour-Fard J (2012). Effect of postharvest salicylic acid treatment on reducing chilling injury in tomato fruit. Romanian Biotechnological Letters 17 (2): 7466-73

Anonymous. (2021). FAO. Statistical database. http://www.fao.org/faostat/en/\#data/QC

Asghari M, Aghdam M S (2010). Impact of salicylic acid on post-harvest physiology of horticultural crops. Trends in Food Science and Technology 21(10): 502-509.

Awad RM (2013). Effect of post-harvest salicylic acid treatments on fruit quality of peach cv." Flordaprince" during cold storage. Australian Journal of Basic and Applied Sciences 7(7): 920-927.

Bal E (2012). Effect of postharvest putrescine and salicylic acid treatments on cold storage of sweet cherries. Süleyman Demirel Üniversitesi Ziraat Fakültesi Dergisi 7(2): 23-31

Davarynejad GH, Zarei M, Nasrabadi ME, Ardakani E (2015). Effects of salicylic acid and putrescine on storability, quality attributes and antioxidant activity of plum cv.'Santa Rosa'. Journal of Food Science and Technology 52 (4): 2053-62.

Erbaş D, Onursal CE, Koyuncu MA (2015). Derim sonrası salisilik asit uygulamasının Aprikoz kayısı çeşidinin soğukta depolanması üzerine etkileri. Meyve Bilimi 2(2): 50-57.

Feng X, Apelbaum A, Sisler EC, Goren R (2004). Control of ethylene activity in various plant systems by structural analogues of 1methylcyclopropene. Plant Growth Regulation 42(1): 29-38.

Gautier H, Diakou-Verdiri V, Benard C, Reich M, Buret M, Bourgaud F, Poessel JL, Veyrat C, Generd M (2008). How does tomato quality (sugar, acid, and nutritional quality) vary with ripening stage, temperature, and irradiance?. Journal of $\mathrm{Ag}$ ricultural and Food Chemistry 56(4): 1241-1250.

Guillen F, Castillo S, Zapata PJ, Martinez-Romero D, Serrano M, Valero D (2007). Efficacy of 1-MCP treatment in tomato fruit: 1. Duration and concentration of 1-MCP treatment to gain an effective delay of postharvest ripening. Postharvest Biology and Technology 43(1): 23-27

Khademi O, Zamani Z, Mostofi Y, Kalantari S, AhMadi A (2012). Extending storability of persimmon fruit cv. Karaj by postharvest application of salicylic acid. Journal of Agricultural Science and Technology 14 (5): 1067-1074.

Luo Z, Chen C, Xie J (2011). Effect of salicylic acid treatment on alleviating postharvest chilling injury of 'Qingnai'plum fruit. Postharvest Biology and Technology 62(2): 115-120. 
McGuire RG (1992). Reporting of objective color measurements. HortScience 27 (12): 1254-1255.

Mostofi Y, Toivonen P M A, Lessani H, Babalar M, Lu C (2003). Effects of 1-methylcyclopropene on ripening of greenhouse tomatoes at three storage temperatures. Postharvest Biology and Technology 27(3): 285-292.

Nunes MCN (2008). Tomato. In: MCN Nunes (ed.), Color atlas of postharvest quality of fruits and vegetables. Blackwell Publishing, Iowa, USA pp. 239252.

Ranjbaran E, Sarikhani H, Bakhshi D, Mehrdad P (2011). Investigation of salicylic acid application to reduce postharvest losses in stored 'Bidaneh Ghermez' table grapes. International Journal of Fruit Science 11: 430-439.

Rao AV, Waseem Z, Agarwal S (1998). Lycopene content of tomatoes and tomato products and their contribution to dietary lycopene. Food Research International 31: 737-741.

Sabir FK, Agar IT (2011). Influence of different concentrations of 1-methylcyclopropene on the quality of tomato harvested at different maturity stages. Journal of the Science of Food and Agriculture 91(15): 2835-2843.

Sabir FK, Unal S, Maadheedi MTK, Mahdi IMM (2019). Extending the Postharvest Quality of Peach Fruits by Salicylic Acid and MAP Treatments. Selcuk Journal of Agriculture and Food Sciences 33(2): 82-87

Sabir FK, Yiğit F, Taşkın S (2013). Fuji Elma Çeşidinde Salisilik Asit Uygulamalarının Soğukta Depolama Süresince Kaliteye Olan Etkileri. Alatarim 12(1): 19-25.
Sayyari M, Babalar M, Kalantari S, Serrano M, Valero D (2009). Effect of salicylic acid treatment on reducing chilling injury in stored pomegranates. Postharvest Biology and Technology 53 (3): 152154.

Sayyari M, Castillo S, Valero D, Díaz-Mula HM, Serrano M (2011). Acetyl salicylic acid alleviates chilling injury and maintains nutritive and bioactive compounds and antioxidant activity during postharvest storage of pomegranates. Postharvest Biology and Technology 60: 136-142.

Sharma SK, Maguer ML (1996). Kinetics of lycopene degradation in tomato pulp solids under different processing and storage conditions. Food Research International 29 (3-4): 309-315.

Tareen MJ, Abbasi NA, Hafiz IA (2012). Effect of salicylic acid treatments on storage life of peach fruits cv.'Flordaking'. Pakistan Journal of Botany 44 (1): 119-124.

USDA, (1991). United Stages standards for grade for fresh tomatoes. United States Department of Agriculture, Agricultural Marketing Service, p.13.

Valero D, Díaz-Mula HM, Zapata PJ, Castillo S, Guillén FN, Martínez-Romero D, Serrano MA (2011). Postharvest treatments with salicylic acid, acetylsalicylic acid or oxalic acid delayed ripening and enhanced bioactive compounds and antioxidant capacity in sweet cherry. Journal of Agricultural and Food Chemistry 59 (10): 5483-5489.

Zhang Y, Chen KS, Zhang SL, Ferguson I (2003). The role of salicylic acid in postharvest ripening of kiwifruit. Postharvest Biology and Technology 28(1): 67-74. 